\section{Marano na ziemi. O jeszcze innej inności Piotra Sommera}

Adam Lipszyc
Artykuł powstał w ramach realizacji grantu NCN „Fenomen maranizmu. Żydowska 'tradycja ukryta' i nowoczesność" (UMO-2017/25/B/HS2/02901).

TEKSTY DRUGIE 2019, NR 4, S. 61-88

DOI: 10.18318/td.2019.4.4 | ORCID: 0000-0002-6425-7812

Nie jestem zatem, jak mawiał Hegel, „dziurą w bycie”, lecz pewnym zagłębieniem, pewnym fałdem, którym powstaje i który może zniknąć.

Maurice Merleau-Ponty

\section{Mniej znaczy więcej, czyli nowa Międzynarodówka}

Niewielka książeczka Jacques'a Derridy Le monolinguisme de l'autre, opublikowana po raz pierwszy w roku 1996, to niezwykła hybryda, która łączy w sobie medytację quasi-autobiograficzną z wywodem filozoficznym dotyczącym relacji między podmiotem a językiem. Esej stanowi eksplikację i uzasadnienie lakonicznej formuły przedstawionej na samym początku tekstu. Formuła ta brzmi: „Mam tylko jeden język i nie jest to mój język”2. Na pozio-

1 M. Merleau-Ponty Fenomenologia percepcji, przeł. M. Kowalska, J. Migasiński, Fundacja Aletheia, Warszawa 2001, s. 235.

2 J. Derrida Jednojęzyczność innego czyli proteza oryginalna, przeł. A. Siemek, "Literatura na Świecie” 1998 nr 11/12, s. 26.

\footnotetext{
Adam Lipszyc -

eseista i tłumacz, pracuje w Instytucie Filozofii i Socjologii PAN, uczy w Szkole Nauk Społecznych, w Collegium Civitas oraz na Uniwersytecie Muri im. Franza Kafki. Laureat nagrody "Literatury na Świecie" im. Andrzeja Siemka, nagrody Allianz Kulturstiftung i Nagrody Literackiej Gdynia. Ostatnio opublikował książkę Freud: logika doświadczenia. Spekulacje marańskie (2019).
} 
mie najbardziej bezpośrednim, empiryczno-autobiograficznym, Derrida stara się w tym zdaniu uchwycić swoją relację do języka francuskiego. $Z$ jednej strony jest rdzennym użytkownikiem tego języka, który postrzega jako swój język macierzysty.Z drugiej strony, jako człowiek urodzony w skolonizowanej Algierii oraz jako Żyd, jest w żywiole kultury francuskiej jednostką podwójnie obcą, francuszczyzna jawi mu się więc jako język nie-swój - tym bardziej, że odbierając na kilka lat obywatelstwo francuskie algierskim Żydom, rząd Vichy dobitnie przypomniał im o ich fundamentalnej obcości.

Warunkiem zaistnienia owej „alienacji bez alienacji”3 - wyobcowania, które zarazem wyobcowaniem nie jest, ponieważ ma charakter źródłowy i dokonuje się w macierzystym języku konstytuującym dopiero właściwy podmiot - byłaby językowa kondycja algierskich Żydów. Zasadniczą rolę odgrywa tutaj okoliczność, że - zdaniem Derridy - poza francuszczyzną społeczność ta nie dysponowała żadnym odrębnym językiem, w którym mogłaby ugruntować własną, stabilną odrębność:

Co do języka w ścisłym znaczeniu, nie mogliśmy się nawet uciec do jakiegoś swojskiego substytutu, do jakiegoś wewnętrznego narzecza wspólnoty żydowskiej, do czegoś w rodzaju języka-schronienia, który by zapewnił, tak jak jidysz, cząstkę intymności, ochronę swojego „u-siebie” przed językiem kultury oficjalnej, dodatkową pomoc w różnych sytuacjach socjosemiotycznych. Dialekt "ladino" nie był praktykowany w Algierii, którą znałem, szczególnie w wielkich miastach, jak Algier, gdzie koncentrowała się ludność żydowska. ${ }^{4}$

W związku z tą sytuacją ową społeczność może Derrida scharakteryzować jako „zdezintegrowaną, rozciętą czy odciętą" i to na trzy sposoby: odciętą od tradycji i języków żydowskich, od języka arabskiego, wreszcie - jako żydowska i jako peryferyjna - od języka i kultury metropolitalnej Francji.

Opis ten przywodzi na myśl znaną charakterystykę sytuacji pisarzy żydowsko-niemieckich, jaką skreślił Franz Kafka w liście do Maxa Broda: „Żyli oni między trzema niemożnościami [...]: niemożnością niepisania, niemożnością pisania po niemiecku, niemożnością pisania inaczej; można by nieomal dodać czwartą niemożność: niemożność pisania [...]. Zatem była to pod każdym względem literatura niemożliwa, literatura cygańska, 
która ukradła niemieckie dziecko z kołyski"s. Derrida odwołuje się do tego listu - choć nie do tego fragmentu - w monstrualnym przypisie dołączonym do Jednojęzyczności innego, w którym stara się porównać językową sytuację algierskich Żydów do lingwistycznego doświadczenia kilkorga ważnych postaci z kontynentu europejskiego. Pisze tu przede wszystkim o Franzu Rosenzweigu, Hannah Arendt i Emmanuelu Lévinasie, lecz także o Gershomie Scholemie, Theodorze Adorno, Paulu Celanie i właśnie o Kafce. Kwestionuje m.in. przeświadczenie Arendt, że można oddzielić język - w jej przypadku: język niemiecki - od wydarzeń historyczno-politycznych i, abstrahując od własnej mniejszościowej kondycji, traktować go jako macierzystą przestrzeń swojskości, która jako jedyna „pozostaje"6. Dla Derridy właśnie ten macierzysty język jest już źródłowo heterogeniczny. Stąd też, rzecz zrozumiała, choć francuszczyzna pozostaje jego żywiołem, poza którym czuje się zagubiony, a w innych językach nie będzie mógł nigdy „zamieszkać”, to również sam język francuski, w którym mieszka, pozostaje dla niego „niemieszkalny”.

W tym punkcie Derrida porozumiałby się chyba z Theodorem Adorno, który charakteryzując kondycję pisarza-emigranta, opisuje, jak ów mości się w swoim pisaniu - „kto utracił ojczyznę, temu pisanie staje się domem” by wreszcie odkryć, że „na koniec pisarzowi nie jest dane mieszkać nawet w pisaniu" ${ }^{\prime \prime}$. O porozumieniu można by tu wszakże mówić jedynie w pewnej mierze, ponieważ racji owej niemieszkalności upatruje Adorno w obowiązującym pisarza-emigranta moralno-poznawczym imperatywie wytężonej uwagi, który w imię zachowania perspektywy krytycznej zakazuje intelektualiście czuć się gdziekolwiek „u siebie”. Derrida nie kwestionowałby raczej kategoryczności owego imperatywu, wskazałby też jednak zapewne, że jest on kwestią nie tyle wolnego wyboru autonomicznego intelektualisty, ile źródłowego naznaczenia, „doświadczenia rany, zniewagi, zemsty i krzywdy”.

Owo naznaczenie decyduje o tym, że Derrida może - autoironicznie, lecz z rozmysłem - zgłosić pretensje do miana osobnika w sposób szczególnie wyrazisty uosabiającego kondycję „franko-maghrebińską". Takie uroszczenie

5 F. Kafka Listy do rodziny, przyjaciół, wydawców, przeł. R. Urbański, W.A.B., Warszawa 2012, s. 376.

6 J. Derrida /ednojęzyczność innego, s. 86-89.

7 Tamże, s. 93.

8 T.W. Adorno Minima moralia, przeł. M. Łukasiewicz, Wydawnictwo Literackie, Kraków 1999, S. 98 .

9 J. Derrida Jednojęzyczność innego, s. 50. 
miałoby być zasadne właśnie ze względu na owo potrójne odcięcie, charakteryzujące społeczność algierskich Żydów. Odcięcie to pozbawiałoby podmiot jakiejkolwiek swoistej tożsamości mniejszościowej, którą dysponowaliby choćby algierscy Arabowie, pozostawiałoby mu zaś jedynie samo tylko niewymazywalne i nieprzezwyciężalne doświadczenie poboczności, uwikłania w kolonialny język, który zarazem jest jego językiem jedynym. W tym właśnie sensie „najbardziej” franko-maghrebińscy byliby franko-maghrebińscy Żydzi. Jak mówi Derrida: „Być Franko-maghrebińczykiem, być nim «jak ja», nie oznacza - nie oznacza przede wszystkim, nie oznacza zwłaszcza - jakiegoś nadmiaru lub bogactwa tożsamości, atrybutów czy nazw. Odsłaniałoby to raczej, najpierw, pewne zaburzenie tożsamości [wyróż. oryg.]"10. Stąd też zresztą Derrida może odżegnać się od choćby częściowej kwalifikacji swojego tekstu jako „autobiograficznego", ponieważ kwalifikacja ta zakładałaby jakieś stabilne „ja”, tymczasem owa wyostrzona „franko-maghrebińskośc” oznacza właśnie trwałą destabilizację podmiotu"11.

Wreszcie, ową (judeo-)franko-maghrebińską destabilizację i językową alienację bez alienacji, jaka miałaby charakteryzować go z racji doświadczenia biograficznego, w tym samym trybie autoironicznej hiperboli przedstawia Derrida jako egzemplaryczną dla ogólnej kondycji podmiotu i jego relacji z językiem, bez względu na rozmaite konstelacje kulturowo-językowe, w jakich żyją ludzie: „Każdy może więc oświadczyć pod przysięgą: mam tylko jeden język i nie jest to mój język, mój «własny» język jest dla mnie językiem nieprzyswajalnym. Mój język - jedyny, który słyszę, gdy mówię, i jedyny, którym się porozumiewam - to język innego"12. Nawet jeśli, rzecz jasna, „wszystkie ekspatriacje pozostają szczególne"13.

Niektóre wątki Jednojęzyczności innego znajdują zajmujące dopełnienie w nieco późniejszym eseju zatytułowanym Abraham, l'autre ${ }^{14}$. Także i tutaj Derrida krąży wokół własnych źródłowych doświadczeń, zasadniczym tematem

Tamże, s. 38 .

Tamże, s. 53.

Tamże, s. 48.

Tamże, s. 95 .

Podstawą tekstu było wystąpienie podczas konferencji, która odbyła się w roku 200o. Esej ukazał się drukiem trzy lata później, czyli na rok przed śmiercią filozofa. Korzystam z przekładu angielskiego. Zob. J. Derrida Abraham, the Other, w: Judeities. Questions for Jacques Derrida, ed. by B. Bergo, J. Cohen, R. Zagury-Orly, trans. B. Bergo, M. B. Smith, Fordham University Press, New York 2007, s. 1-35. 
nie jest już jednak stosunek podmiotu do języka, lecz takie rozumienie żydowskości, w którym Derrida mógłby się rozpoznać bez zafałszowania. Jak można wnioskować już choćby z lektury Jednojęzyczności innego, jest to żydowskość tyleż ułamkowa i śladowa, co niewymazywalna i zasadnicza. Co więcej, ową ułamkowość Derrida czuje się w obowiązku chronić, otaczając swoją żydowskość parkanem niedomówień i częściowych zatajeń. Nie dlatego jednak - jak zapewnia - by kryć się ze swoim „pochodzeniem”, lecz po to, by za sprawą nazbyt donośnych deklaracji ta ułamkowa-acz-zasadnicza żydowskość nie okrzepła fałszywie w esencjalną tożsamość wyznawcy judaizmu lub członka pewnej wspólnoty narodowej. Idzie tu zatem o „milczenie, które chronię i które mnie chroni, o sekret, który być może trzyma mnie $z$ dala od [wyróż. oryg.] judaizmu, ale też zarazem utrzymuje we mnie pewną żydowskość. [...] To tak jakbym [...] musiał trzymać się z dala od judaizmu, by zachować w sobie to, co prowizorycznie określam mianem żydowskości. [...] Trzymaj się z dala od tego, byś zachował tego czegoś cząstkę, trzymaj się z dala od bycia Żydem, po to byś mógł pozostać Żydem"15. W dalszej części wywodu Derrida przyznaje zresztą, że owej „żydowskości” nie można w sposób chemicznie czysty od ,judaizmu” oddzielić. Nie jest to ani jakaś odrębna esencja, ani czysto formalna struktura, lecz raczej pewna nieesencjalna, a zarazem empirycznie ukształtowana, kulturowo-biograficzna resztka.

Ta właśnie logika pozwala zrozumieć, w jaki sposób Derrida pojmuje fenomen maranizmu. Derridiański marano to właśnie osobnik, który trzyma się z dala od stabilnej tożsamości żydowskiej, przekonany, że tylko w skrajnie zindywidualizowanej, ułamkowej, niezagadanej postaci zachowuje swoją „żydowskość" i to - tu znów samoświadoma przesadnia - w najlepszy możliwy sposób. Szczególnie jawne, a w swoim chucpiarstwie poniekąd rozbrajające sformułowanie tej logiki mniej-czyli-więcej (czy wręcz ledwie-co-ale-właśnie-w-tej-postaci-dopiero-to-co-trzeba-czyli-po-prostu-wszystko) odnajdujemy w następującym fragmencie:

Jak gdyby ten, kto najbardziej się zapierał i kto - jak się zdawało - zdradził dogmaty przynależności, czy byłaby to przynależność do wspólnoty, do religii, nawet do ludu, narodu czy państwa itd. - jak gdyby [wyróż. oryg.] ten właśnie osobnik jako jedyny reprezentował ostatni wymóg, hiperboliczne żądanie tej właśnie sprawy, którą jakoby zdradził w wyniku krzywoprzysięstwa. Stąd właśnie to prawo, które mnie dotyka, prawo, 
które - z pozoru antynomijne - w sposób przedwczesny i niejasny, w blasku nieugiętego światła, narzuciło mi hipersformalizowaną formułę losu poświęconego sekretowi - i stąd też coraz chętniej całkiem poważnie igram z figurą marana: im mniej ukazujesz się jako Żyd, tym lepszym Żydem będziesz. ${ }^{16}$

Derrida nie pozostawia również wątpliwości co do tego, jakie doświadczenie miało źródłowy, decydujący i niewymazywalny wypływ na kształt jego żydowskości. Było to mianowicie doświadczenie jadowitego antysemityzmu w kolonialnej Algierii. „Zabiło” w nim ono, jak zapewnia autor Widm Marksa, "elementarne zaufanie do jakiejkolwiek wspólnoty” - w tym również do wspólnoty żydowskiej"17. Ze względu na źródłowy charakter tej stygmatyzacji ze strony otoczenia Derrida także i w tym wypadku nie potrafi i nie chce oddzielać losu od wyboru. Trzymając się swojego „maranizmu”, kultywuje coś, co spadło na niego bez jego udziału, kondycję naznaczonej jednostki o zaburzonej tożsamości, która nie może i nie chce odzyskać stabilizacji w odrębnej wspólnocie mniejszościowej. Odróżniony, naznaczony i wypchnięty ze stabilnej pozycji podmiotowej, nieodwołalnie zdecentrowany, a jednocześnie przecież nieodwołalnie zlokalizowany, trwa w żywiole swojej, a zarazem nie-swojej francuskości jako element zakłócony - i uporczywie zakłócający jej homogeniczną hegemonię (Derrida: „homo-hegemonię”), która „wciąż działa w kulturze, prostując fałdy i rozkładając tekst na płask"18. Co więcej, jako osobnik o tożsamości sprowadzającej się właściwie wyłącznie do owego zakłócenia, które wszelako wynika przecież z wyraziście jednostkowych biograficzno-geograficzno-lingwistycznych doświadczeń, jest tyleż chemicznie czystym nadprzykładem, wzorcem uniwersalnej dynamiki alienacji bez alienacji, co i bytem arcyposzczególnym, którego empiryczna pojedynczość stawia pod ironicznym znakiem zapytania czysto formalny charakter prawidła jego losu. Ostatecznie więc wyśrubowana do granic wytrzymałości, bezczelna autohiperbola obraca się pomyślnie we własne przeciwieństwo: jeśli Derrida nie chce ani zaprezentować się jako byt zgoła abstrakcyjny, ani zażądać dla siebie jakiejś wybrańczej, substancjalnej tożsamości, musi na koniec rozpoznać się jako jeden z wielu podobnych-acz-za-każdym-razem-innych, jako

\footnotetext{
16 Tamże, s. 13.

17 Tamże, s. 15.

18 J. Derrida Jednojęzyczność innego, s. 64.
} 
jeden z członków pewnej „nowej Międzynarodówki”" którzy kultywują doświadczenie zlokalizowanej nieprzynależności.

\section{Otwock jako Algieria, czyli Piot-huź na gałązce}

Jednojęzyczność innego ukazała się w polskim przekładzie pióra Andrzeja Siemka w roku 1998, w podwójnym numerze „Literatury na Świecie” (11/12). Numer ten, w znacznej mierze poświęcony właśnie twórczości francuskiego filozofa, któremu rok wcześniej nadano doktorat honoris causa na Uniwersytecie Śląskim - w tym samym zeszycie „Literatura na Świecie” publikowała także wykład Derridy wygłoszony z tej okazji - opatrzony został komentarzem Piotra Sommera, który tym numerem domykał swoje pięciolecie jako redaktora naczelnego. Ów krótki esej, zatytułowany Już leży na desce, stanowi coś w rodzaju stronniczego przeglądu wypowiedzi, jakie pojawiły się w polskiej prasie w związku z wizytą Derridy. Sommer drwi z ignoranckich napaści na autora $O$ gramatologii, piętnujących go jako bełkotliwego niezrozumialca, niebezpiecznego relatywistę i papieża postmodernizmu, który śmie kwestionować to, czy świat jest aby na pewno taki, jak nam się zdaje:

Obowiązuje siermiężna pycha i pełnia księżycowej naiwności. Dumał, nie dumał, carom nie budiesz, zwłaszcza że wiadomo już, kto dziś car i autorytet (no kto, no kto? - no ja, media!).,Wszyscy” wiedzą najwyraźniej, jaki jest świat, a dziennikarz ich w tej wiedzy jedynie upewni i lud swój wykształcony z upodlenia podniesie, tylko przy okazji mianując się owego ludu („wszystkich”) rzecznikiem i przedstawicielem. ${ }^{20}$

Co więcej, jak z rozbawieniem odnotowuje Sommer, w reakcji na wizytę Derridy powstało coś w rodzaju jednolitego frontu, który połączył publicystów reprezentujących skonfliktowane zwykle opcje ideowe: z jednej strony Michała Cichego, w ówczesnym wcieleniu sekretarza nagrody Nike i głównego machera od kultury w liberalnej „Gazecie Wyborczej”, z drugiej zaś Bogusława Wolniewicza i Ryszarda Legutkę, chętnie udzielających się w mediach profesorów filozofii o wyraziście prawicowych poglądach. Wszyscy oni najwyraźniej ujrzeli w Derridzie zagrożenie dla prawdziwych norm i zasad, a w istocie dla świętego spokoju i kojącej bezmyślności: „I co niby

19 Tamże, s. 92.

P. Sommer Już leży na desce, "Literatura na Świecie” 1998 nr 11/12, s. 279. 
daje mu prawo burzenia tego, co myśmy w pocie czoła zbudowali i pojęli - trudne dzieciństwo w Algierze?"21. Stając na straży ignorancji, media okazują się zarówno przejawem, jak i głównym narzędziem utwierdzania homo-hegemonii:

Oto jak z okazji obrony równin Mazowsza przed niewygodnym obcym zawiązuje się interesujący alians między krzewicielami wartości, wywodzącymi się do tej pory z parafii ponoć odmiennych. No, jednak pewne sprawy - dzieńdoberek, to właśnie my! - łączą nas mocniej, niż dzieli barwa harcerskiej chusty. Odmienność? różnica? - chwileczkę: czyż nie są to słowa rodem z obłego żargonu, którego nie da się „wyłożyć po ludzku"? Żaden obcy nie będzie nam tu przecież dekretował różnic. ${ }^{22}$

Esej Sommera, świadectwo intelektualnej niepodległości i językowego wyczulenia autora, to z pewnością bystra diagnoza stanu polskiej kultury medialnej i pozamedialnej końca lat 9o., a zarazem analiza medialnych odruchów jako takich. Tekst ten zwraca jednak uwagę przede wszystkim własnym istnieniem. Naczelny „Literatury na Świecie” nie ma raczej w zwyczaju opatrywać numerów pisma wstępniakami (czy nawet - jak w tym wypadku- ulokowanymi pod koniec numeru „zstępniakami”). Także okoliczności, w których zrobił wyjątek od tej reguły, mogą zrazu wydać się nieco osobliwe. Sommer nie kojarzy się bowiem natychmiast z jakimś żywszym zainteresowaniem dyskursami teoretycznymi w ogóle, a filozofią w szczególności, nawet jeśli jest to filozofia krążąca wokół literatury lub granicę literackości sama przekraczająca. Co więcej, naczelny „Literatury na Świecie” był do tego tekstu na tyle przywiązany, że przedrukował go w tomie eseistyki Po stykach zadedykowanym pamięci Andrzeja Siemka, tłumacza Jednojęzyczności innego ${ }^{23}$.

Ten wyjątkowy, choć przecież poboczny tekścik odczytywałbym jako wyraźny sygnał, że Sommer rozpoznał w Derridzie swojego człowieka - zwłaszcza w Derridzie z Jednojęzyczności innego, od której, jak zaświadcza ów „zstępniak", wyszedł pomysł na cały numer derridiański. Co więcej, wydaje mi się, że jest to rozpoznanie trafne. Że mianowicie przy wszystkich zasadniczych

Tamże, s. 281.

Tamże.

Zob. P. Sommer Już leży na desce (wzwiq̨zku z układaniem numeru "Literatury na Świecie" poświęconego /acques'owi Derridzie), w: tegoż Po stykach, wyd. 2, zmienione, WBPiCAK, Poznań 2018, s. 339-347. 
rozbieżnościach wynikających zarówno z odmiennych trajektorii biograficznych, jak i z odmiennych mediów wyrazu, te dwie osobności - Derrida i Sommer - przeglądają się w sobie i nawzajem oświetlają. W szczególności zaś sądzę, że Derridiańska medytacja nad własną podwójną innością, która właśnie dzięki tej podwójności staje się innością hiperboliczną - zgodnie z autoironiczną zasadą, że to franko-maghrebińscy Żydzi są Franko-maghrebińczykami "jako takimi” - pozwala zrozumieć to i owo z anatomii owej „podmiejskości”, którą tak pracowicie kultywuje podmiot stojący za twórczością Sommera. Podmiejskość ta nie umożliwia wszak pełnego zakorzenienia w jakiejś - za przeproszeniem - małej ojczyźnie i ku takiemu zakorzenieniu wcale się nie wyrywa. Jest ekscentrycznością zlokalizowaną, drobnym, ale zasadniczym przesunięciem w obrębie homo-hegemonicznej i scentralizowanej polskości. Dla jej anatomii zasadnicze znaczenie ma chyba właśnie to, że w jej wnętrzu jątrzy się jeszcze inna inność, która decentruje samą tę podmiejską ekscentryczność i - zgodnie z logiką Derridy - dopiero czyni ją prawdziwie nieprzezwyciężalną, sama ku żadnej substancjalnej, odrębnej tożsamości nie prowadząc. Jest to inność źrodłowo zasadzająca się przede wszystkim na wykluczeniu i stygmatyzacji, sygnalizowana nieomylnie, ale z rzadka i tylko tyle, ile trzeba, żeby potwierdzić i utwierdzić ekscentryczność głosu mówiącego w tych wierszach, ale nie zagadać jej nazbyt donośnymi deklaracjami akcesu do jakiejś osobnej wspólnoty. W myśl Derridiańskich definicji podmiot tego głosu to pewien szczególny marano, niesubstancjalny fałd w swoim/nie-swoim języku.

Spośród wszystkich wierszy, jakie wyszły spod pióra Piotra Sommera, najsilniej nasycone odniesieniami do judaizmu i świata żydowskiego wydają się jego przekłady z Charlesa Reznikoffa. To trochę tak jakby, przyjmując służebną rolę tłumacza, Sommer pozwalał sobie na intensywność nawiązań, na którą nie decyduje się raczej w swoich autorskich utworach. A przecież i w tym wypadku idzie przede wszystkim o żydowskość wyrazistą, ale zaznaczaną bez hałasu, rozproszoną w codzienności i w znacznej mierze zeświecczoną. Przywołajmy dwa kluczowe, poniekąd komplementarne przykłady. W przejmującym poemacie Kadysz podmiot głosu mówiącego w wierszu stara się powiedzieć prostymi słowami o umieraniu i śmierci matki. W dziesiątej, przedostatniej cząstce poematu bliscy skupiają się przed portretem zmarłej, ale nie są w stanie ani na nią patrzeć, ani - właśnie z racji bliskości - o niej mówić „pomiędzy sobą". W cząstce ostatniej wszakże w miejsce tej krępującej niemożności zjawia się w jakiejś mierze kojące, ciche porozumienie między mówiącym (czy raczej milczącym) a samą zmarłą: 
Wiem, że nie gniewasz się

(jeśli się w ogóle gniewasz)

że się za ciebie nie modlę

lub że nie palę świecy

w rocznicę twojej śmierci:

te głupstwa nie są potrzebne

między nami -

modlitwy i słowa i świece. ${ }^{24}$

Modlitwy i inne rytualne głupstwa nie są potrzebne „między nami”. I choć tytuł wiersza mógłby sugerować liturgiczne uwznioślenie codzienności,język poematu, delikatny i zwykły, opiera się takiej transformacji i prędzej już ucodziennia modlitwę, wiarygodnie zastępując zrytualizowane frazy, ostatecznie zaś tworząc miejsce dla niewzniosłego, intymnego milczenia ${ }^{25}$.

O ile w Kadyszu Reznikoff przyjmuje perspektywę ultraprywatną, w wierszu Jozue w Sychem ogarnia szerokim spojrzeniem naród żydowski jako na przemian skupiajacą się i rozpraszającą całość - i stara się nazwać po imieniu jego wygnańczą kondycję. Rzecz kończy się słowami pięknymi i dobitnymi, które chyba z racji swojej przewrotnej mądrości potrafią unieść niemałą dawkę patosu:

\section{I rozproszył ich Bóg -}

po miastach Medskich, i nad wodami Babilonu;

uciekli przed Nim do Egiptu i popłynęli na okrętach w stronę morza;

połykały ich wieloryby,

wieść o nich przynosiły królowi ptaki;

młodzi czekali na nich z bronią w ręku,

starcy z przysłowiami -

i spojrzał Bóg, i zobaczył Hebrajczyków,

obywateli wielkich miast,

mówiących po hebrajsku w każdym języku pod słońcem. ${ }^{26}$

Ch. Reznikoff Kadysz, w: tegoż Co robisz na naszej ulicy, wyb., przeł. i opr. P. Sommer, WBPiCAK, Poznań 2019, s. 128.

Wedle świadectwa samego Sommera Kadysz był pierwszym wierszem Reznikoffa, z jakim przyszły autor Dni i nocy w ogóle się zetknął. P. Sommer Ucieczka w bok (pytania i odpowiedzi), WBPiCAK, Poznań 2016, s. 108 („To było dojmująco piękne”). 
To oczywiście potężny, po prostu zapierający dech w piersiach fragment, w którym rozpoznałoby się wielu współczesnych maranów. Warto też jednak zwrócić uwagę, że choć Reznikoff spogląda tutaj na rozproszoną wielość marańskich wygnańców, z których każdy kultywuje swoją żydowskość w swoim/ nie-swoim języku wielkiego miasta, ową rozmaitość uchyleń homo-hegemonicznego języka decyduje się mimo wszystko określić mianem hebrajszczyzny, a całość wiersza ująć w formę biblijnej stylizacji. Gest ten stanowi z pewnością jedno z zasadniczych źrodeł siły tego wiersza, zarazem jednak kreśli zarys spoistości i jedności, który dla takiego choćby Derridy mógłby okazać się już odrobinę nazbyt wyrazisty.

W autorskich wierszach Piotra Sommera tak mocnych gestów raczej się nie wykonuje. Nie ma tu biblijnych stylizacji, nie przywołuje się z imienia formuł liturgicznych czy świętego języka, nawet jeśli formuły te miałyby zostać zastąpione przez świecką mowę i intymność milczenia, a język ów miałby rozproszyć się w mnogości narzeczy wielkich miast. Jedyny znany mi przypadek, w którym Sommer igra z frazą zaczerpniętą z tradycji judaistycznej, przedstawia się nader odmiennie. Idzie mianowicie o jeden z krótkich utworów zgromadzonych pierwotnie w tomie Wiersze ze słów, zatytułowany Kuchnia polska:

Kartkują, kartkują, a potem mówią że wszystko tam jest. ${ }^{27}$

Sommer bawi się tutaj nawiązaniem do pewnego znanego fragmentu talmudycznego traktatu PirkejAwot. Oto tanaicki mędrzec Ben Bag-Bag miał jakoby powiedzieć: „Przewertuj i przekartkuj (Torę). W niej jest wszystko”28. W błazenkującej parafrazie Sommera talmudyczne pouczenie, które zaleca nieustanny nawrót do Księgi zawierającej w sobie całość objawienia i wszelką mądrość potrzebną człowiekowi, przemienia się w językowy twór wysoce

27 P. Sommer Kuchnia polska, w: tegoż Po ciemku też (wiersze z książek), WBPiCAK, Poznań 2013, S. 295.

28 Sentencje Ojców (Pirkej Awot), przeł. M. Friedman, "Literatura na Świecie” 1987 nr 4, s. 25. W przekładzie Szymona Datnera i Anny Kamieńskiej: „Badaj ją wzdłuż i wszerz, albowiem w niej jest wszystko". Z mądrości Talmudu, wyb., przeł. i opr. Sz. Datner, A. Kamieńska, PIW, Warszawa 1992, s. 86. Por. także wersję zaproponowaną w sumiennym wprowadzeniu do Talmudu (przełożonym z angielskiego przez kompetentą hebraistkę): „Przewracaj ją (Torę), kartkuj nieustannie, gdyż wszystko jest w niej zawarte". A. Cohen Talmud, przeł. R. Gromadzka, Cyklady, Warszawa 2002, s. 146. Dopisek w nawiasie pochodzi od Cohena. 
migotliwy pod względem retorycznej tonacji, wymowy, przedmiotowego odniesienia i rejestru kulturowego. Torę zastępuje tutaj odwieczna książka kucharska, której tytuł donośnie obwieszcza jej narodową przynależność. Zmiana imperatywu na tryb oznajmujący powoduje też zakłócenie sensu tego „kartkowania”: ze słowa, które miało odsyłać do podejmowanych raz po raz prób odnalezienia w Księdze odpowiedzi na nurtujące nas akurat pytanie, staje się ono słowem, które zaczyna sugerować lekturę nieuważną i zdawkową. Przeglądają tylko, a potem robią mądrą minę i mówią: Panie, tam jest wszystko, każdy głupi to wie! Albo: Kochana, nie wiedziałaś? Tam wszystko jest! Skupienie i rozproszenie, rejestr mądrościowy i codzienno-kuchenny, żydowski i polski gadają ze sobą w obrębie tego krótkiego utworu, odpowiadają sobie nawzajem echem i zrazu nie sposób ustalić, której stronie - jeśli którejkolwiek - należy przyznać pierwszeństwo. Można sobie wyobrazić, że podmiot głosu mówiącego w tym wierszu, czytając fragment Pirkej Awot, słyszy w nim echa kuchennych gadek. Albo, z drugiej strony, że utarta fraza rzucona w rozmowie wywołuje w jego pamięci pogłos talmudycznej frazy.

Ostatecznie jednak nie ma tu chyba pełnej symetrii. Właśnie dlatego, że wiersz nosi tytuł odsyłający do arcypolskiej codzienności, to żydowska aluzja zajmuje pozycję sekretnego podtekstu, a nie na odwrót. Sekretem tego przekazu pozostaje wszakże samo to aluzyjne, marańskie odchylenie, nie zaś żadna ezoteryczna treść. Wiersz Sommera nie skrywa w sobie przejścia ku jakiejś zagubionej tajemnicy, nie potrafi też spowodować, by w samej Kuchni polskiej można było odnaleźć coś więcej: możemy ją sobie kartkować w najlepsze i choć mówią, że wszystko tam jest, i tak nie dogrzebiemy się do Księgi. Wiersz sprawia tylko, że pogłos tej ostatniej - albo raczej pogłos tego, co się o niej mawiało - pobrzmiewa w potocznych gadkach o całkiem polskiej książce kulinarnej, na którą odtąd będziemy patrzyli trochę inaczej. To chyba wystarczy za dyskretne, ale całkiem solidne odkształcenie homo-hegemonicznego języka².

Barbara Klicka z Uniwersytetu Muri im. Franza Kafki zwróciła mi uwagę na nieco odmienny sposób odczytania tej miniatury. Za pośrednictwem aluzji do Talmudu wplecionej w ten utwór podmiot mówiący w wierszu wskazywałby może, że choć niby w tej arcypolskiej książce kucharskiej „wszystko jest”, ale dla niego samego miejsce chyba się nie znalazło - nawet jeśli przynajmniej w jednym z wydań Kuchnia polska uwzględnia przepis na karpia po żydowsku (w dziale przystawki). Zob. http://www.publio.pl/files/samples/da/fb/ec/121568/Kuchnia_polska_Przystawki_zupy_dania_glowne_desery_demo.pdf (dostęp 31.12.2018). Zarazem należałoby chyba zaznaczyć, że samo to aluzyjne oskarżenie działa jak cichy wyrok i jego przebiegła egzekucja: wiersz odkształca Kuchnię polską i robi w niej trochę miejsca. 
Jako się rzekło, taka rozmowa z figurami tradycji judaistycznej należy do rzadkości w poezji Sommera - choć jednostkowość i niewielki rozmiar Kuchni polskiej nie umniejsza wagi tego wiersza. Z jednym jeszcze wyjątkiem, bodaj wszystkie inne utwory, w których zaznacza się obecność tego, co żydowskie, nie tyle grają z żydowską materią kulturową, ile przywołują obrazy i frazy związane z historią wyosobnienia, stygmatyzacji i prześladowania - z historią gestów, które definiują pozycję outsiderską. Bodaj najwcześniejsze tego rodzaju odwołanie pojawia się w wierszu Babcia, opublikowanym w debiutanckim tomie Wkrześle:

$[\ldots]$ ja byłem
panem olesiem dwudziesto-
czteroletnim kuzynem
zmarłym na suchoty u
wód i na tyfus
w getcie $^{30}$

Sprzeczne relacje dotyczące śmierci „pana olesia” rozdwajają jego tożsamość: to, być może, splątane wersje podawane na przemian przez babcię przy różnych okazjach i wobec różnych rozmówców - wersja elegancko-polska, spoza której czasem wychynie mniej fotogeniczna wersja żydowska. Gra wersyfikacyjna - „dwudziesto - / czteroletnim” - powoduje, że migocze też wiek pana olesia: kuzyn raz ma tyle lat, ile miał, gdy umarł, raz tyle, ile, być może, ma obecnie wnuk, którego z panem olesiem babcia myli².

Późniejsze wiersze Sommera zahaczające czy zahaczone o to, co żydowskie, krążą najczęściej wokół jednego z trzech punktów ośrodkowych: Marca'68, figury kirkutu i antysemityzmu, by tak rzec, codziennego. Marzec przywoływany jest bezpośrednio w trzech utworach z tomu Kolejny świat (Odwiedziny, W piwnicy, Emik Laine), za każdym razem w charakterystycznym dla

P. Sommer Babcia, w: tegoż Po ciemku też, s. 19.

31 Dzięki wersyfikacyjnej grze migotliwość semantyczno-tożsamościowa uruchamia się zresztą w tym wierszu już wcześniej: babcia kłania się przed lustrem, a „staruszka / w lustrze też kiwała / głową ja byłem / panem olesiem itd." Może być więc tak, że "głową ja byłem”, tj. że babcia nie rozpoznaje się w lustrze, a zamiast siebie widzi wnuka, którego z kolei myli z panem olesiem. $\mathrm{Na}$ temat tego wiersza i kilku innych, przywoływanych poniżej utworów dotykających dziecięcego doświadczenia żydowskości i antysemityzmu zob. K. Kuczyńska-Koschany Sommer, chłopak, w: P. Śliwiński (red.) Wyrazy życia. Szkice o poezji Piotra Sommera, WBPiCAK, Poznań 2010, s. $163-166$. 
„politycznych" rzeczy Sommera splocie publicznego z prywatnym i za każdym razem jako zasadnicza cezura dziejowo-życiowa. Wiersze W piwnicy i Emik Laine nie odnoszą się wszakże - przynajmniej nie bezpośrednio - do antysemickiego wymiaru wydarzeń marcowych. Dobitne odniesienie tego rodzaju odnajdujemy natomiast w wierszu Odwiedziny. O ile jednak to, co myśli sobie o tych wydarzeniach podmiot głosu mówiącego w wierszu, nie ulega raczej wątpliwości (myśli źle), o tyle warto odnotować, że perspektywę, z której ów głos mówi, można identyfikować na dwa sposoby. Z jednej strony podmiot tego głosu może być członkiem prześladowanej społeczności. Gdybyśmy przyjęli tę identyfikację, to właśnie do owej społeczności (rzecz u Sommera wyjątkowa) odnosiłoby się owo „my”, które w dzierżawczej postaci zjawia się we fragmencie wiersza: „One wszystkie też wyjechały. / Nasze piękne

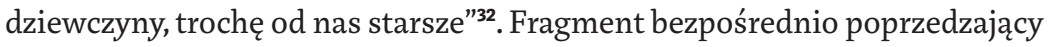
te dwa wersy - „Było mi wstyd podwójnie, / za siebie i za to wszystko” - musiałby wówczas znaczyć: było mi wstyd za to, co się wyprawia w tym kraju i za to, że ja sam - choć należę do tej społeczności - nie wyjeżdżam. Z drugiej strony jednak nic nie stoi na przeszkodzie, by podmiot głosu mówiącego w tym wierszu zidentyfikować jako osobnika, który - mimo ścisłych związków z prześladowaną społecznością - sam do niej nie przynależy. Wówczas uznalibyśmy, że owo "my" nie odnosi się do wspólnoty narodowej, tylko do grupy splecionej więzami przyjaźni czy miejsca zamieszkania, a podwójność owego wstydu wyłożylibyśmy, mówiąc, że w takich sytuacjach wstyd człowieka osobnego zawsze jest podwójny: wstydzi się za większościową społeczność wypychającą właśnie pewną mniejszość poza granice państwa i za samego siebie jako mimochcianego członka tej większości. Przemyślnie poluzowany język wiersza dopuszcza obie identyfikacje, a tym samym tożsamość podmiotu mówiącego w wierszu - a dokładniej: jego wspólnotowa przynależność - pozostaje niejednoznaczna.

Tego rodzaju poluzowania - wprowadzane za pomocą rozmaitych środków językowych - pojawiają się także w odniesieniu do figury kirkutu. Żydowski cmentarz, zniszczony i zapuszczony, nawraca w wierszach Sommera przede wszystkim jako obce, martwe ciało kwestionujące spoistość swojskiego krajobrazu. W Liście z Kijowa mówiący w wierszu przypomina sobie „o Azerbejdżanach" w swojej „starej szkole (i o rozbitym w proch / kirkucie tuż za miastem) / i wszystkich małych / narodach świata"33. W Kresce odnajdujemy 
się w niejednoznacznej przestrzeni prawdopodobieństwa, poza strefą oddziaływania zaimków dzierżawczych i wyrazistych identyfikacji, „prawdopodobnie w jakimś małym mieście / które się dobrze zna lub w którym / było się choć raz czy dwa, / z sosnami i domami z drzewa, / knajpą, kościołem, wymarłym kirkutem" ${ }^{\text {"34 }}$. To dzierżawczo-identyfikacyjne poluzowanie powoduje zresztą, że ów kirkut, który wpasowywałby się w aliteracyjny ciąg z knajpą i kościołem, lecz za sprawą „wymarcia” od tego ciągu odskakuje, jako kulturowo wyraziście określony i obcy tym bardziej rzuca się w oczy ${ }^{35}$.

W miniaturze A to co znowu z tomu Wiersze ze stów efekt natarczywej obecności tego, co wymazane, uzyskany zostaje natomiast za pomocą środków poniekąd przeciwstawnych. Zamiast identyfikować pewną przestrzeń jako kirkut czy w ogóle jako pewien cmentarz, Sommer inscenizuje coś w rodzaju wstawki nasyconej zdumieniem i niejaką irytacją, wrzutki przerywającej gładką wymianę zdań podczas hipotetycznej przechadzki:

\section{A to co znowu}

Płaskie płyty sterczą z trawy

za murem. ${ }^{36}$

Jeszcze bardziej aluzyjna, a zarazem jeszcze bardziej niepokojąca i dobitna jest inna miniatura $\mathrm{z}$ tego samego tomu:

\section{Bratki}

Wszystkie brązowe oczy gniją już pod ziemią. ${ }^{37}$

TegożKreska, tamże, s. 86.

W szkicu Po stykach kirkut umiejscowiony jest całkiem jednoznacznie w Otwocku, ale i tu w sposób otwarty mówi się o nim jako o obiekcie przemocy ze strony wspólnoty większościowej, nie zaś jako o przestrzeni, gdzie potwierdza się własną przynależność do wspólnoty odrębnej: „I najchętniej bym opowiedział [...] może również o tym, jak ci pensjonariusze i pensjonariuszki - czasem przyjeżdżający się podleczyć z dość daleka - umierali, zazwyczaj wiosną albo jesienią, i jak niektórych, czasami nawet tych z Odessy, chowano na kirkucie w lesie za kanałem, a ich czaszki wykopywali sobie koledzy z mojej klasy. Wojtek latami, jeszcze na Budrysów, miał jedną na pianinie". Tegoż Po stykach, w: tegoż Po stykach, s. 331.

Tegoż A to co znowu, w: tegoż Po ciemku też, s. 292.

Tegoż Bratki, tamże, s. 293. 
Sommer wyodrębnia tutaj fragment wiersza Podstuch z tomu Dni i noce: „I nie ma jak uniknąć piwnego wzroku bratków / których prawie nie ma dziś na klombach, / wyparły je nasturcje i aksamitki. Nie ma też klombów. / Wszystkie brązowe oczy gniją już pod ziemią"38. Wyodrębnienie to wzmaga z pewnością efekt grozy i uwypukla aluzyjny potencjał wydzielonej frazy, a nawet gdybyśmy nie znali tego dłuższego wiersza, nie moglibyśmy uniknąć wzroku bratków, choć przecież te gniją już pod ziemią. Usytuowana w pozycji tytułu miniatury nazwa kwiatu zawiera w sobie z pewnością ładunek, który - aktywowany mógłby przerodzić się w pełną deklarację przynależności i identyfikacji („oto moi bracia"), trwa on jednak domknięty w kontekście botanicznym, podcięty zdrobnieniem i ewentualnym pogłosem niepatetycznych frazeologizmów („no, mój bratku”). Kiedy zaś w miniaturze Kwatermistrz znajdziemy się może najbliżej sytuacji,w której podmiot głosu mówiącego w wierszu wskazywałby jakiś cmentarz jako własny, wówczas ani nie pojawi się tu żadne „ja”, ani też w końcu nie powie nam się wprost, który to właściwie cmentarz. Wplącze nas się tylko - i aż - w ironiczno-autoironiczną grę, która od deklarowanych asymilacji i oswojeń wyprowadzi nas znowu w pole wyobcowania. Na koniec możemy wręcz zwątpić, czy ów cmentarz na pewno wybraliśmy sobie sami, czy też wskazuje nam go ktoś inny, rozpoznając nas jako obcych i kwitując frazą w rodzaju „no, ci to wiadomo gdzie się pochowają":

Się trochę oswoiło -
ludzie, kraj
i cmentarz
też wiadomo który. ${ }^{39}$

Uderzający kontrapunkt dla tych poluzowań i aluzji tworzą utwory, w których całkiem otwarcie mówi się o antysemityzmie. Co istotne, za każdym razem idzie w nich przede wszystkim o dojmującą przemoc językową - przemoc intencjonalnych napaści lub bezmyślnie powtarzanych fraz. Co równie istotne, za każdym razem, gdy podmiot głosu mówiącego w wierszu identyfikuje się jako ten, kto obrywa lub oberwał, przywołuje jakąś scenę ze swojego dzieciństwa ${ }^{40}$. Ta regularna koniunkcja dziecięctwa i jawnych odwołań

38 Tegoż Podsłuch, tamże, s. 364.

39 Tegoż Kwatermistrz, tamże, s. 296.

40 Ewentualnym wyjątkiem od tej prawidłowości jest wiersz Chinatown, gdzie mówiący, całkiem dorosły, stara się nie wściekać na przeczytany „w skądinąd, hm, przyzwoitej gazecie” tytuł 
do antysemityzmu wydaje się bardzo ważna: w tych utworach przywołany zostaje podmiot dziecięcy wystawiony w blasku dnia i dosłowności na bezpośrednie działanie przemocy werbalnej, która dopiero wyśle go na drogę wyosobnienia, tożsamościowych komplikacji i marańskich strategii przemilczeń ${ }^{41}$. Tak jest z pewnością w wierszu Jakiś dtuższy czas temu. Tutaj dwie dziewczynki, w bardzo codziennych okolicznościach, w niby to (i poniekąd naprawdę) swojskiej, podmiejskiej przestrzeni pooznaczanej znajomymi nazwami („na ulicy Warszawskiej obok / dawnej «Grażynki»”) rozprawiają o tym, że "gdyby Hitler nie pozabijał Żydów, oni / kazaliby nam teraz czyścić sobie buty".

I przeraziłem się, i po powrocie

spytałem Matkę, a ona powiedziała

żebym się nie martwił. ${ }^{42}$

Wyraźne echo antysemickich wyzwisk, tym razem zapewne wymierzonych bezpośrednio w mówiącego, słychać też w wierszu Nic się nie stało, gdzie matka znów występuje w roli cokolwiek bezradnej pocieszycielki: „klitka w Otwocku, słowo klitka, zapach starej kobiety, która jest moją babką, Mama też była mała, Pan Jezus też był Żydem" ${ }^{\text {43. }}$.

Wśród utworów z tej grupy szczególne miejsce zajmuje poemat Spóźniony list. Wiersz, ujęty w formę listu do francuskiego dziadka ze strony matki, którego nadawca nigdy nie poznał, stanowi wielką medytację nad tożsamością piszącego. Pisanie do nieobecnego i nieznanego adresata otwiera przestrzeń dla sekwencji pytań dotyczących własnej, rzekomo ustalonej tożsamości, która w kontaktach z otoczeniem tak skutecznie pozoruje spoistość, w istocie zaś pozostaje wysoce niejasna. W tej medytacji, nasyconej autobiograficznym szczegółem, Sommer wykonuje szczególny twist: niby to przy okazji pisania do dziadka z Francji - i pisania o nim - mówi się tu całkiem sporo o żydowskich członkach rodziny, nawet jeśli nie umie się o nich powiedzieć zbyt wiele. Są

"Dlaczego Żydzi zabili Jezusa?" - tu jednak nie jest jasne, czy sam należy do owego etnosu zabójców (a zatem, czy sam czuje się obiektem przemocy symbolicznej), czy też złości się i wstydzi jako członek wspólnoty większościowej. Tegoż Chinatown, tamże, s. 157. Powyższe sformułowania zawdzięczam rozmowie z Barbarą Klicką (UMFK), której niniejszym składam stosowny ukłon. 
tu „i Chaim, i Fajga”, rodzice ojca, „o których, podobnie jak o nim, nic nie wiem do dziś”, jest sam ojciec, „który nie skończył bodaj czterech klas / w chederze”, jest matka matki („Myślę, że w porządnej francuskiej rodzinie / w tamtych czasach ożenić się / z Żydówką też nie było łatwo") ${ }^{44}$. Ów twist robi szczególne wrażenie w jednym z centralnych fragmentów, gdzie - podobnie jak w kilku innych punktach poematu - mówi się o wstydzie:

Najbardziej to mi potem było wstyd że nie nauczyłem się twojego języka.

Może mama zaczęła mnie uczyć za wcześnie, kiedy wolałem wziąć przylepkę i iść na podwórko (czy tak już musi zostać?

Colette raz powiedziała, że mógłbym mówić całkiem dobrze). Na podwórku dzieci też mi o tym przypominały, wołały piot-huź, piot-huź, jakby wiedziały i koniecznie chciały się tym ze mną podzielić, że przyjechałeś z Francji. Ale wkrótce zrozumiałem, że szło o inny kraj, to znaczy o innego dziadka.

(Nie wiem, jak to się stało, że one wiedziały wtedy o tym lepiej ode mnie. $)^{45}$

Jedna obcość - jako obcość z istoty swojej trochę przykra, ale w wersji francuskiej w miarę może szykowna - pomieszała się tu z drugą obcością, o wiele bardziej nieapetyczną. Dokładniej: tę drugą obcość chciałoby się wziąć za tę pierwszą - no, ale przecież się nie da. Mniejszościowe zniekształcenie języka powraca echem w stygmatyzującym przezwisku zniekształcającym imię dziecka, którego niepełna przynależność do podwórkowego społeczeństwa władającego jakże poprawną polszczyzną zostaje tym samym ugruntowana w sprawczym akcie mowy. Za to wykluczenie, stawiające pod znakiem zapytania jego tożsamość, osobnik o zniekształconym imieniu - kiedy już podszkoli się w sztuce marańskich podchodów - odpłaci później, zaburzając statystyki podwórka zwariowanym, sarkastycznym rachunkiem mnogości, który wprawia w dygot zazwyczaj sprawnie funkcjonujące operatory inkluzji

\footnotetext{
44 Tegoż Spóźniony list, tamże, s. 69, 70, 71. 
i ekskluzji. Ten rachunek wypracuje w wierszu Można wspaniale iść: „Jeszcze jeden mężczyzna, z tygodniowym zarostem, gdzieś koło czterdziestki, zawołał przez jezdnię z włoska «Antonio!», ale ten do którego wołał też był Polakiem, tak samo jak ja i «pięć dziesiątych procenta» innych, tylko o dziesięć lat bardziej zniszczonym"46.

Spóźniony list to najdłuższy, a zarazem ostatni wiersz w tomie Pamiątki po nas. Wiersz najkrótszy, a zarazem pierwszy stanowi wyjątek na tle zarysowanej mapy odwołań do tego, co żydowskie. Rzecz wygląda następująco:

\section{Wiersz}

Ach, spać, spać,

potrafi spać jak ptaszek na gatazce

- Julian Stryjkowski

a jednak wciąż widzieć

spod zaciśniętych powiek!47

Motto utworu pochodzi z powieści Sen Azrila, a w tekście Stryjkowskiego nie ma akurat wątpliwości, kto jest podmiotem tego zdania. W pełnej postaci brzmi ono bowiem: „Żyd potrafi spać jak ptaszek na gałązce"48. Wymazując podmiot zdania zaczerpniętego od pisarza, który sam o maranach pisywał niemało, Sommer dokonuje iście marańskiego przemilczenia ${ }^{49}$. W miejsce wyrazistego znaku przynależności etniczno-kulturowej rodzi się podmiot niejasny, widmowy, niby zabawny, może zabawowy, zironizowany zdrobnieniami i patetycznym „ach", a jednak taki, którego nie sposób zbyć tak łatwo, pacyfikując go jakąś wspólnotową etykietą. Niepewny swojej tożsamości, zaniepokojony i niepokojący, ten marano na ziemi czuwa nawet we śnie i nawet we śnie widzi wszystko spod zaciśniętych powiek. Nadmiernym uproszczeniem byłoby zapewne powiedzieć, że to nie żaden człowiek, że to tytułowy „wiersz”, byt czysto językowy utrzymujący się w stanie wystudiowanej niejasności, „potrafi spać jak ptaszek na gałęzi”. Na pewno jednak osobnik,

\footnotetext{
46 Tegoż Można wspaniale iść, tamże, s. 99.

47 TegożWiersz, tamże, s. 29.

48 J. Stryjkowski Sen Azrila, Czytelnik, Warszawa 1975, s. 28.

49 Zob. J. Stryjkowski Przybyszz Narbony, Czytelnik, Warszawa 1983 i,Na wierzbach... nasze skrzypce", Czytelnik, Warszawa 1974.
} 
o którego chodzi, poza wierszami tak całkiem nie istnieje, cały bowiem - jak wiadomo - zawiera się w „międzysensach”: „włazi tam, gdzie widzi trochę miejsca"50.

\section{Geopoetyka pojedynczości, czyli dekonstrukcja ma głos}

Marano na ziemi to łobuz w języku, który jako istota o zakłóconej tożsamości stawia opór homo-hegemonii w swojej/nie-swojej mowie i z innymi łobuzami się rozpoznaje - także z tymi, co od innej strony drążą inne języki ${ }^{51}$. Nie tyle jednak utożsamia się z nimi w ramach jakiegoś czysto abstrakcyjnego porządku, ile rezonuje z ich pojedynczością, wzmacnia ją w krytycznym nasłuchu i sam czerpie z niej siłę. Derrida formował „nową Międzynarodówkę" opornych. Sommer, w tonacji mniej podniosłej, pisze o permanentnej autodydaktyce:

Często nie obchodziła mnie twórczość poetów, którzy uchodzą za wybitnych, dopóki nie znalazłem u nich czegoś dla siebie - na przykład dopóki nie dosłyszałem u nich czegoś, co naruszałoby schemat oczekiwań wobec polskiego wiersza. I zdarzało mi się dosłyszeć to coś również u poetów obcych - co naruszało jakieś oczekiwania tam. Wtedy do pewnego stopnia przestawali być dla mnie obcy. [...] W każdym razie podminowanie, podcięcie, naruszenie, podważenie, wzbogacenie via to wszystko - to zawsze wydawało mi się najżywsze. [...] Sam się ciągle doszkalam u różnych odmieńców i odmieńczyń. ${ }^{22}$

To „doszkalanie się", które realizuje się przede wszystkim w trybie lektury i przekładu, oznacza w praktyce metodyczne tkanie sieci czy raczej siatki odmieńców, obejmującej tak różne postacie jak Konstandinos Kawafis, który „mówił spoza centrum - mówił z Aleksandrii, myślał z Aleksandrii, chodził do kawiarni w Aleksandrii, chodził do łóżka z chłopcami w Aleksandrii, i z Aleksandrii «psuł» tym niechętnikom z kontynentalnej Grecji

P. Sommer Niedyskrecje, w: tegoż Po ciemku też, s. 135.

Jeśli chodzi o apologię „łobuza” czy „bandyty”, który psuje wizję narodowego „braterstwa” i rozbija kolisko wspólnotowej samotożsamości, zob. J. Derrida Rogues: Two Essays on Reason, przeł. P.-A. Brault, M. Nass, Stanford University Press, Stanford 2005, zwł. s. 63.

P. Sommer Ucieczka w bok, s. 210. 
grecki język"53, Miron Białoszewski czy poeci irlandzcy, tacy jak wczesny Seamus Heaney („chłopiec z boku”), wczesny Paul Muldoon, Derek Mahon czy Ciaran Carson ${ }^{54}$.

Te działania na rzecz odmienności w języku polskim i niepolskim, działania, w których samopouczenie łączy się z nienachalnym pouczeniem innych i subwersyjnym uwypukleniem cudzego "podwłosiarstwa”, obejmują także Sommerową praktykę krytyczno-literackąa . Weźmy dwa szczególnie spektakularne przykłady, z których niemal mimochodem wyłania się cała geopoetyka pojedynczości, marańska geopoetyka pisania, czytania i przekładu. W eseju Nie okrzyczane zwycięstwo zjadaczy kartofli, poświęconym cyklowi wierszy Juliana Kornhausera zatytułowanemu Hurrraaa!, gdzie poeta użycza głosu postaciom rozmaitych klas i profesji, Sommer zwraca uwagę, z jaką precyzją Kornhauser wychwytuje rozmaite intonacje języka i jak oszczędnymi środkami je zaznacza. I tak np. kresowego zaciągania nie trzeba sygnalizować za pomocą nieortograficznego zapisu: „Żeby dać czytelnikowi do zrozumienia, skąd pochodzi górnik opowiadający o zawale w kopalni - Kornhauser nie musi dośpiewywać czytelnikowi zmiękczeń, ani w ogóle nic dopisywać. Wystarcza to, co dyktuje sama składnia - «od szóstej zaczęli my słyszeć stuki» - a słuch dopisuje mu nieomylnie" ${ }^{\text {"56 }}$. Gdy słuch nam dopisuje, różnica akcentu dopisze się do tekstu sama, odkształcając go, jak należy.Ta subtelność gestu, który pokłada zaufanie w słuchu, a nie stawia grubych diakrytycznych kresek, decyduje zdaniem Sommera o tym, że miniatury Kornhausera, każda z osobna, przeobrażają się w coś większego niż tylko sprawozdanie z jednostkowego wydarzenia lingwistycznego - w ogólniejszą figurę osobności. W tym punkcie jednak Sommer wprowadza zasadnicze zastrzeżenie, które odróżnia gest Kornhausera od gestów jego niegdysiejszego towarzysza poetyckiej broni: „Ale detal - znowu - uniwersalizuje się niepostrzeżenie i od niechcenia, bez natręctw paraboli, bez pouczeń. Kto tam mówi, że «Lwów jest wszędzie»? Mówi się «od szóstej zaczęli my słyszeć stuki»"

53 Tamże, s. 202.

54 Tegoż Co ciekawiło mnie u Seamusa Heaneya, kiedy zaczynałem go tłumaczyć i Poeci irlandzcy, poeci polscy, w: tegoż Po stykach, s. 167-182 i 196-205, zwł. s. 176-181, 204-205.

55 Tegoż Ucieczka w bok, s. 203.

56 Tegoż Nie okrzyczane zwycięstwo zjadaczy kartofli, w: tegoż Smak detalu i inne ogólniki, WBPiCAK, Poznań 2015, s. 109.

57 Tamże. 
Mam ten passus za jedno ze szczytowych osiągnięć Sommera jako eseisty. Zderzając podniosły finał poematu Adama Zagajewskiego Jechać do Lwowa z obcesowo przygodną frazą górnika-kresowiaka podsłuchanego przez Kornhausera, Sommer mówi właściwie wszystko, co trzeba. Po jednej stronie sytuuje się mowa górna, w której - przypuszczalnie - próbuje się wyrazić myśl o uniwersalności wygnańczej kondycji, wyraża się jednak w sposób tak dęty, że kłamie własnej prawdzie i przeobraża się w tubalny teoremat, który podmiot całkiem nieźle osadzony w sobie deklamować może na międzynarodowych festiwalach literackich. Po drugiej stronie sytuuje się język uporczywie konkretny, który - podsłuchany, zacytowany i może podretuszowany przez poetę - ulega, owszem, uniwersalizującemu wzmocnieniu, ale nie ulatuje ku pustemu formalizmowi czy szykownemu zakorzenieniu-w-ekspulsji, lecz trwa w swojej osobności i z tej osobności wchodzi w kontakt z wszystkimi innymi osobnościami tego świata. Tym samym, skrywając się za opisowo-nakazową dwuznacznością frazy „mówi się” i nieco może łagodząc perswazyjność tego zdania szczyptą autoironii, Sommer przeprowadza wyraziste rozróżnienie i stawia bardzo mocną, normatywną tezę. Warto też przypomnieć, że tuż przed konkluzją głoszącą wszechobecność Lwowa nader liryczny podmiot wiersza Zagajewskiego uskarża się: „dlaczego każde miasto / musi stać się Jerozolimą i każdy / człowiek Żydem"58. Tego, chyba nie tylko gwoli oszczędności, ale i przez grzeczność Sommer nie przytacza: z punktu widzenia marańskiej Międzynarodówki takie wielkopańskie westchnienia i fałszywe uniwersalizacje zasługują wyłącznie na pominięcie.

Drugi przykład dotyczy wiersza obcojęzycznego, kwestii przekładowych i pojedynczości ugruntowanej - a jednak - w pewnym znaku diakrytycznym. Idzie mianowicie o esej Sommera poświęcony poezji Miroslava Holuba. Tutaj także stawką jest uwolnienie się od natręctw paraboli, do której w tym wypadku skłonność ma sam komentowany poeta. Sommer bierze na warsztat wiersz zatytułowany Napoleon, który podaje we własnym przekładzie. W wierszu Holuba nauczyciel wypytuje uczniów o Napoleona, ci zaś udzielają na chybił trafił sprzecznych odpowiedzi i jasne jest, że wódz niewiele ich obchodzi i że nic o nim nie wiedzą. Zwrot następuje wraz z interwencją jednego z nich, Františka:

U nas jeden rzeźnik miał psa który nazywał się Napoleon, mówi František. 
Rzeźnik go bił i pies umarł

z głodu

rok temu.

I wszystkie dzieci litują się teraz

nad Napoleonem. ${ }^{59}$

Według Sommera, zasadniczy ruch utworu polegałby na - zamierzonym przez autora - przejściu od wielkiej historii ku prywatności, ku konkretowi naszego „podwórka”. To jasne. Ów zwrot wydaje się wszakże zagrożony przez paraboliczne upodobania Holuba, które popychały go w stronę pisania wierszy językowo jak najbardziej przezroczystych, w jak najmniejszym stopniu opierających się przekładowi. Sommer nie mówi tego wprost, ale logika jego wywodu prowadzi w stronę sugestii, że te skłonności Holuba mogłyby zneutralizować ów uposzczególniający ruch wiersza, tak iż cała rzecz rozpłynęłaby się w pustej ogólności teorematu. A jednak pewien element, zauważa Sommer, blokuje tę dialektyczną odwrotkę i niesie w sobie całą siłę ujednostkowiającego pouczenia: jest nim konkretne imię chłopca, który zabiera głos, imię wyposażone na dodatek w nieprzekładalny znak diakrytyczny - w owego „ptaszka” nad „s”. Ten ptaszek, mówi Sommer, wisi nad krajobrazem czy podwórkiem, w istocie zaś to podwórko zawieszone jest na owym ptaszku, to on bowiem strzeże jego pojedynczości. I ostatecznie to ten właśnie ptaszek stanowi gwarancję pojedynczości głosu, który przeciwstawia się nauczycielskim, ogólnym mądrościom:

Tutaj nagle osią jego, Holubowej, paraboli, decydującą o wszystkich najważniejszych sensach, jest to, co nijak nie da się przełożyć, co wręcz musi pozostać nieprzeniesione, by dalej mogły się nieść odrębność i znaczenie (odrębność czyli znaczenie?) i żeby dalej dawało się być sobą („być sobie jednym”, jak ćwierknął kiedyś Miron Białoszewski): ptaszkiem nad podwórkiem. [...] Jeśli więc morał, to nie wprost, morał naopak [tytuł tomu Holuba - przyp. A.L.], wbrew autorowi, który tak bardzo chciał wypełnić ideał przekładalności, że „pod przekład” pisał. A tutaj wiersz mu dęba staje, František się wymyka aplikacji, ptaszyna odwraca się ogonem i - niespodzianka? - dalej po czesku wisi sobie nad podwórkiem. ${ }^{60}$ 
Być może i w tym przypadku możemy pójść o krok dalej w stronę, którą wskazuje Sommer, i powiedzieć, że w całej swojej nieprzekładalnej pojedynczości i nieprzejrzystości ptaszek ten ukazuje się dopiero w przekładzie, dopiero wtedy wzbija się do lotu nad podwórkiem. Właśnie w przekładzie, który gwoli bycia przekładem należytym musi ulec nieprzekładalności imienia (czy też znaku diakrytycznego, który stanowi tego imienia znak najszczególniejszy) odsłania się raz jeszcze, w jeszcze inny sposób, uniwersalna acz konkretna osobliwość. Nawet jeśli nie przedłużymy w ten sposób linii Sommerowego rozumowania, także i w tym wypadku możemy dostrzec, jak autor Kuchni polskiej - drążąc konkretny przykład i stroniąc od teorii - rozwija coś, co pozwoliłem sobie nazwać geopoetyką pojedynczości: koncepcję (potencjalnie uniwersalnej) przestrzeni językowej pełnej komunikujących się ze sobą, lecz trwających w wyosobnieniu, jedynych w swoim rodzaju odchyleń.

Zakłócenie tożsamości podmiotu wyrastające z doświadczenia zdwojonej inności, apologia językowych naruszeń, obrona pojedynczości, nieprzekładalność imienia - wszystkie te motywy czynią Sommera duszą naturalnie derridiańską. Jest jednak pewien zasadniczy motyw, który w pisaniu Sommera pełni funkcję zasadniczą, w przypadku Derridy zaś może umknąć uwadze lub zostać zignorowany jako czysta retoryka. Idzie mianowicie o prymat głosu i konwersacyjnego myślenia o języku ${ }^{61}$. Jak wiadomo, lwia część późniejszych wierszy Sommera to wydarzenia konwersacyjne, inscenizacje przytoczeń, porozumień i nieporozumień, które na dodatek nieustannie czytelnika zagadują, proces lektury przeobrażając w nieustannie nawiązywany i zrywany proces rozmowy. Jeśli idzie o quasi-teoretyczne deklaracje Sommera w tym względzie, miejscem tymczasem już klasycznym jest jego esej o Bohdanie Zadurze. Czytamy tu m.in.:

Dość dobrze znam opinię, wedle której mniej czytelny punkt wiersza to jakoby wyraz arogancji autora wobec „zwykłego człowieka”. Rzadziej słyszy się zdanie, że arogancją grzeszy ten, kto owego zwykłego człowieka redukuje do poziomu naiwnego odbiorcy prostackich pogadanek umoralniających, upatriotyczniających, ureligijniających, czy jakich tam jeszcze. Mam w tym przypadku na myśli pogadanki tak zwane poetyckie. Dlaczegóż to wszystko bez wyjątku miałoby być czytelne dla każdego?

61 Na temat konwersacyjnego aspektu poezji Sommera wyczerpująco i kompetentnie pisze Joanna Armatowska w rozprawie doktorskiej zatytułowanej Dyskretna czułość świata. O konwersacyjnym i paidetycznym wymiarze poezji lerzego Ficowskiego i Piotra Sommera (Poznań 2019). 
W ostatnim tomie Zadury znajduję zdanie: „Coś musi zostać niejasne”, i jego treść nie kłóci się z zasobami dostępnego mi doświadczenia. Musi zostać niejasne, mimo wszelkie próby wyjaśnień, dogadania się; mimo wszystkie komentarze i przypisy. [...] Wiersz to rozmowa; rozmowa jest po to, żeby się porozumieć, ale bez uproszczenn. ${ }^{62}$

Sommer bliski jest tu sformułowania smakowitego, dekonstrukcyjnego paradoksu: jeśli lektura wiersza miałaby polegać nie tyle na tym, byśmy wystawiali się na powszechnie zrozumiałe (i w swojej zrozumiałości zarozumiałe) pouczenie, ile na tym, byśmy wchodzili $\mathrm{z}$ wierszem $\mathrm{w}$ rozmowę, to $\mathrm{w}$ takie rozumienie lektury z konieczności wpisany jest moment niezrozumiałości, którego nie będzie można wyeliminować z tekstu - chyba że za cenę wypłaszczenia jego konwersacyjnych fałdów i zamrożenia właśnie w postaci „zrozumiałej” pogadanki. I choć Sommer nominalnie mówi tu o dwóch postawach autorskich, rozwija też zarazem pewną koncepcję czytania, która każe dosłuchiwać się w tekście konwersacji - tam, gdzie to tylko możliwe. Innymi słowy, rzuca wskazówki kierujące w stronę czegoś, co można by określić mianem „dekonstrukcji wokalnej”, dekonstrukcji, która ma głos. To strategia lektury, która odchodzi od hermeneutycznego gromadzenia znaczeń, w mniejszym stopniu jednak zmierza ku aktywizacji tekstualnej gry znaczącego, w większym zaś - ku ożywieniu czasem kakofonicznej wielogłosowości i wewnętrznej, performatywnej rozmowności utworu oraz ku wydobyciu wszystkich momentów, w których tekst zagaduje czytelnika. Taka lektura dosłuchuje się pojedynczości tonów, nie pozwala im zgubić się w ogólności zrozumiałego przekazu i właśnie gwoli ocalenia tego, co pojedyncze, godzi się z nieusuwalnym momentem niezrozumienia.

Jeśli uznalibyśmy, że warto forsować tę wokalną mutację dekonstrukcji, nie od rzeczy byłoby czytać nie tylko Sommera w świetle tekstów Derridy, lecz także Derridę - przez pryzmat Sommera. Dostrzegłoby się wówczas, o ile oczywiście nie zauważyło się tego wcześniej, w jak wielkim stopniu zwłaszcza późniejsze teksty Derridy, tego filozofa „pisania”, zaangażowane są w wokalny, a nie tekstualny sposób myślenia o języku, i w jak wielkim stopniu same wdają się w konwersacyjne praktyki. Dostrzegłoby się też wówczas, że ten aspekt jego twórczości nie ma (wyłącznie) charakteru irytującego ornamentu, który utrudnia dotarcie do właściwej argumentacji. Inscenizowaną rozmową

62 P. Sommer Nowy Jork jak włostowicki cmentarz (o nowych wierszach Bohdana Zadury), w: tegoż Smak detalu, s. 148-149, i 156-157. 
między różnymi wersjami „ja” jest - między innymi - sama Jednojęzyczność innego, gdzie Derrida raz po raz wikła się w lokalne mikrokonwersacje i o samym rozmawianiu rozmawia. Jeden z najważniejszych fragmentów, w których do tego dochodzi, mówi też o samych warunkach możliwości rozmowy i o tym, co jej zagraża:

Te słowa nie przychodzą mi na usta, nie wychodzą mi z ust. Niech inni mówią: „mój język ojczysty”. Oto moja kultura; nauczyła mnie ona nieszczęść, w które może wtrącić ludzi magiczne przywoływanie języka ojczystego. Moja kultura była od razu kulturą polityczną. „Mój język ojczysty": to właśnie mówią i nim mówią, a ja ich cytuję i pytam. Pytam ich - w ich języku oczywiście, żeby mnie zrozumieli, bo to rzecz poważna - czy dobrze wiedzą, co mówią i o czym mówią. Zwłaszcza wtedy, gdy tak sobie lekko celebrują „braterstwo”: to w gruncie rzeczy ten sam problem - bracia, język ojczysty itd. To trochę tak, jakby marzyło mi się, że ich budzę, by im powiedzieć: „Słuchajcie, uwaga, dość tego, trzeba wstać i odejść, bo inaczej zdarzy wam się nieszczęście lub, co niemal na jedno wychodzi, nie zdarzy się wam nic. Nic prócz śmierci. Wasz język ojczysty, to co tak nazywacie, pewnego dnia, zobaczycie, nawet wam nie odpowie. Dalej, w drogę. Słuchajcie... nie wierzcie tak szybko, wierzcie mi, że jesteście narodem, przestańcie słuchać bez protestu tych, co wam mówią «słuchajcie»..." ${ }^{" 3}$

Derrida wdaje się tutaj w wyimaginowaną rozmowę z „braterską" wspólnotą homo-hegemonicznego „języka ojczystego", cytuje, jątrzy i zadaje pytania, inscenizując przy tym konwersacyjne sfałdowania mowy. Autoironiczny finał tego passusu, w którym dochodzi do głosu świadomość potencjalnej śmieszności i samowywrotności tego rodzaju tyrad, co same mogą przerodzić się w aż nazbyt dobrze zrozumiałe pouczenia, dookreśla jedynie kruchą pozycję podmiotu, który raz po raz stara się zainicjować wokalną dekonstrukcję nadmiernie spoistych wypowiedzi i dosłuchać się w nich niekoniecznie zgranego chóru pojedynczych głosów. Ten podmiot, marano wplątany w swój/ nie-swój język francuski, polski czy jakikolwiek inny, siłą rzeczy musi być oczywiście nader nietrwały, cały jest bowiem tylko sekretnym zakłóceniem, pozbawionym wewnętrznej, odrębnej substancji fałdem, który może w każdej chwili zniknąć. Póki co jednak uporczywie ciągnie dalej swoją krecią,

63 J. Derrida Jednojęzyczność innego, s. 58. 
dekonstrukcyjną robotę. W pewnym wierszu, który wchodzi w niezwykły rezonans z Derridiańską Jednojęzycznością innego, Piotr Sommer nazwał tę robotę po imieniu z oszałamiającą precyzją starannie odmierzonych dwuznaczności - zarazem nieomal nazywając samego siebie. Tę "piosenkę" określił autoironicznie mianem „pasterskiej”, w istocie jednak śpiewa ją ów szczególny marano na ziemi:

Czytaj te parę zdań, jakbym był

obcym, innym

językiem, którym może wciąż jestem

(choć mówię twoimi słowami, posługuję się

twoimi słowami);

którym byłem mówiąc

twoim językiem,

stojąc za tobą i słuchając

bez słowa,

śpiewając

w twoim języku

moją melodię.

Czytaj, jakbyś miał słuchać,

nie rozumiećc ${ }^{64}$.

64 P. Sommer Piosenka pasterska, w: tegoż Po ciemku też, s. 259. 


\section{Abstract}

\section{Adam Lipszyc}

INSTITUTE OF PHILOSOPHY AND SOCIOLOGY OFTHE POLISH ACADEMY OF SCIENCES

Marrano on Earth: Another Otherness of Piotr Sommer

Lipszyc explores the "Marrano" aspect of Piotr Sommer's poetic and essayistic work. The starting point is Jacques Derrida's essay Monolingualism of the Other, where Derrida outlines his understanding of Marranism and the condition of localised non-belonging. Derrida's perspective allows Lipszyc to describe the traces of Judaism in Sommer's poetic work - which are key precisely because they are no more than traces. Most of all, their presence determines the specific status of "suburban" outsiderness. Sommer's essays also build on such a defined, eccentric position. Here he traces and foregrounds analogous perspectives that focus on the singularity of the subversive voice. Ultimately, his strategy of critical reading can be identified as Marrano vocal deconstruction.

\section{Keywords}

Piotr Sommer, Jacques Derrida, Marrano, deconstruction, voice 